frequencies. It is generally superior, however, to the electrostatic or thermal types for speed of response, constancy of calibration, temperature coefficient and other qualities, so that considerable effort has been made by designers to overcome its limitations at the higher frequencies, and the useful frequency-range may yet be extended above $10 \mathrm{kc} . / \mathrm{s}$. to $20 \mathrm{kc} . / \mathrm{s}$. Many useful practical details of the design and use of the instruments are interspersed with the theory, and the advantages and accuracy of the varions types are indicated. Electrostatic and electromagnetic coupling effects are discussed briefly in one section, and the pamphlet concludes with a few remarks about three-phase power measurements.

\section{Science Progress}

THE latest number of Science Progress (43 ; July 1955 ) is once more a combination of interesting articles on various aspects of science, shorter descriptions of recent advances in astronomy, physics, meteorology, organic chemistry, geology and botany, some notes on researches and items of interest to scientific workers and the usual comprehensive and valuable list of book reviews. The articles include one on animal communication and the origin of human language by Prof. J. B. S. Haldane, statistical physics and its problems by Prof. C. Domb, aromatic halogenation by Prof. P. W. Robertson, and one by Dr. A. G. Lowndes on the use of the Wolf Rock phonolite as a means of tracing deepwater drift in the English Channel.

\section{Recent Earthquakes}

During May-July the greatest earthquake (magnitude $7 \frac{1}{4}$ ) occurred on May 30 in the Volcano Islands (lat. $24 \frac{1}{2}^{\circ} \mathrm{N}$., long. $142 \frac{1}{2}^{\circ} \mathrm{E}$.), and seven other earthquakes caused damage. The most extensive damage was on July 20 at Cotacachi in Northern Ecuador; on July 16 moderate damage was done in the Agean on Samos and at Soke in Turkey, where about five hundred houses were totally or partially wrecked, four people killed and twenty others injured. Minor damage was done on May 7 in California, May 11 in Ecuador, May 21 in Samoa, May 22 in Austria, and June 5 in Algeria. In Europe, earthquakes were felt in Switzerland (May 2 and 22, and June 16, 17 and 26), Germany (May 12, June 26 and July 2), France (May 12), Norway (June 3) and Spain (June 4). The epicentre of the German earth tremors was in the Onstmettingen-Pfeffingen-Tailfingen triangle, and they were felt with scale 5 (Modified Mercalli) on June 26 and scale 4 on July 2. The epicentre of the Norwegian earth tremor on June 3 was near Sognefjord. Aftershocks of the Orleansville (Algeria) earthquake have continued, and strong earthquakes have been numerous in the Aleutian Islands. On June 28 an earthquake occurred in the north polar region (lat. $86 \frac{1}{2}^{\circ}$ N., long. $70^{\circ} \mathrm{E}$.) with magnitude 6. The greatest depth of focus during the three months was $700 \mathrm{~km}$. for an earthquake on May 11 with epicentre at lat. $7^{\circ}$ S., long. $123 \frac{1}{2}^{\circ}$ E., in the Banda Sea; and an earthquake with depth of focus $650 \mathrm{~km}$. occurred on June 11 with epicentre at lat. $16 \frac{1}{2}^{\circ} \mathrm{S}$., long. $179^{\circ} \mathrm{W}$., near the Fiji Islands.

\section{Courses in Radiological Physics and Health Physics at the University of Chicago}

THE University of Chicago has approved of two new courses leading to the M.S. degree in radiological physics or in health physics, both degrees being awarded by the Department of Radiology. The courses are full-time and last two years, the second of which is spent half on academic work and half in service in the Department at a nominal rate of pay. The work includes physiology, biochemistry, biophysics, anatomy, toxicology and radiological physics. Before they can be accepted, students must have completed the equivalent of the University of Chicago B.S. degree in physics. The courses will commence this autumn. Further information can be obtained from Prof. Lester S. Skaggs, Department of Radiology, University of Chicago, 950 East 59th Street, Chicago 37, Ill.

\section{Biological Aspects of the Transmission of Disease}

A SYMPOSIUM is being arranged by the Institute of Biology on "Biological Aspects of the Transmission of Disease", to be held at the London School of Hygiene and Tropical Medicine during September 29October 1. Speakers will be drawn from all fields of biology concerned with disease transmission-bacteriology, virology, parasitology and plant pathology. The papers are being arranged in sessions, not by the organism transmitted, but by the method of transmission, that is, passive, direct, or indirect. In order that there can be a useful discussion, preprints will be available before the meeting for those intending to be present. Programmes for the symposium are available from the Institute of Biology, Tavistock House South, Tavistock Square, London, W.C.1.

\section{Announcements}

THE British Society of Rheology is holding a symposium on "Surface Rheology" at the Washington Singer Laboratories, University College, Exeter, during September 22-24. In the evening of September 23 the Society will hold its annual general meeting. Further information can be obtained from the honorary secretary, Dr. P. Feltham, The University, Leeds 2.

The Industrial Section of the Royal Microscopical Society is organizing a symposium and exhibition under the title "Fibre Microscopy", to be held on November 16 at the rooms of the British Pharmaceutical Society, Bloomsbury Square, London, W.C.1. The papers and exhibits will include work with both the optical and electron microscope, and will be concerned with a large variety of fibres. Further information can be obtained from the Society at Tavistock House South, Tavistock Square, London, W.C.1.

THe eleventh British Commonwealth and Empire Lecture of the Royal Aeronautical Society will be given by Dr. J. J. Green at 6 p.m. on October 6 at the Royal Institution, 21 Albemarle Street, London, W.1. Dr. Green, who is the representative on the Canadian Joint Staff in Washington of the Canadian Defence Board, will speak on "The Growth of Aeronautical Research in Canada during the Post-War Decade". He was the first president of the Canadian Aeronautical Institute, founded in 1954. Further information can be obtained from the Secretary of the Society at 4 Hamilton Place, London, W.1.

WE regret that the obituary notice of Prof. G. F. Shirras in Nature of August 27, p. 376, was unsigned ; it was written by Dr. John Murray, formerly principal of University College, Exeter. 